\title{
Analysis of the thermal comfort model in an environment of metal mechanical branch
}

\author{
Pinto, N. M. ${ }^{*}$, Xavier, A.A.P. ${ }^{2}$ and Regiane T. do Amaral ${ }^{3}$ \\ ${ }^{l}$ Instituto Federal do Espirito Santo, Coordenadoria de Segurança do Trabalho - Vitória, Brasil \\ ${ }^{2}$ Universidade Tecnológica Federal do Paraná, Depart. Eng ${ }^{a}$ de Produção -Ponta Grossa, Brasil \\ ${ }^{3}$ Instituto Federal do Espírito Santo, Subgerência de Administração Geral - Cariacica, Brasil
}

\begin{abstract}
This study aim s to identify the correlation between the Predicted Mean Vote (PMV) with the therm al sensation (S) of $55 \mathrm{em}$ ployees, establishing a linear multiple regression equation. The m easurement of environm ental variables followed established standards. The survey was conducted in a metal industry located in Ponta Grossa of the State of Parana in Brazil. It was applied the physical model of thermal comfort to the environmental variables and also to the subjective data on the thermal sensations of employ ees. The survey was conducted from May to November, 2010, with 48 measurements. This study will serve as the basis for a dissertation consisting of 72 measurements.
\end{abstract}

Keywords: predicted mean vote, thermal sensation, employees, environmental variables, thermal comfort.

\section{Introduction}

\subsection{Thermal comfort}

Thermal comfort according to a response of one of the participants "is a pleasant sensation of temperature that makes you want to work". The air temperature is one of $t$ he envi ronmental variables to be measured. There are four personal and two envi ronmental vari ables $t$ hat are measured and tabulated in studies of therm al comfort environment.

But what exactly is Thermal Comfort? It is defined in [11] as "That condition of mind which expresses satisfactio $n$ with th ermal environment". ISO has a defi nition that expresses one's imagination as to th eir contentment in hot, cold or pleasant place. However, when speaking about thermal comfort, there is need for measurements that are standardized with parameters that can be compared and analyzed.
Thermal comfort is the individual's satisfaction with the thermal co nditions of the environment.

According to [7] early study on comfort assessed how the hygrometric thermal conditions affected labor perform ance. These studies have proposed the creation of $t$ hermal com fort indexes, which sought to encompass in a si ngle parameter, sev eral $v$ ariables as th e activity exerted by the person, $t$ he type of cl othing and environmental parameters that provided the heat exchanges between $\mathrm{t}$ he body and $\mathrm{t}$ he environment. In $\mathrm{t}$ he group cl assified as theoretical indexes, the one proposed by [6], and also those proposed by $[8,15,16]$ are highlighted.

According to [18] the basis of the studies on thermal comfort is found in the thermal balance between $\mathrm{m}$ an and $\mathrm{t}$ he envi ronment around hi $\mathrm{m}$. These studies were impelled by Fanger's studies on climate cham bers (1970), i n Denm ark and they are standardized in [11].

"Corresponding author e-mailnormapintodemelo@gmail.com 
The equation of heat balance, according to the heat exchange between body and environment is given by equation [1]:

Thermal comfort is given by:

$M-W=Q_{S K}+Q_{R E S}$

where:

$\mathrm{M}=$ metabolic rate of heat production $\left(\mathrm{W} / \mathrm{m}^{2}\right)$;

$\mathrm{W}=$ rate of mechanical efficiency $\left(\mathrm{W} / \mathrm{m}^{2}\right)$;

$Q_{S K}=\mathrm{t}$ otal rat e of heat loss through the skin $\left(\mathrm{W} / \mathrm{m}^{2}\right)$;

$Q_{R E S}=$ total rate of heat loss through breathing, $\left(\mathrm{W} / \mathrm{m}^{2}\right)$;

Men have a very effective thermal control system of the tem perature that ensures that the body $\mathrm{t}$ emperature i s about $37^{\circ} \mathrm{C}$. W hen body temperature increases, there is a peripheral vascular expansion, the blood flows increases to the skin causing the person starts to sweat.

The evaporation of sweat takes the heat off the body, keeping it at about $37^{\circ} \mathrm{C}$. W hen the body begins to cool, the blood vessels constrict, reducing blood flow to the skin, and i ncreasing internal heat product ion by st imulating $t$ he muscles to tremble. The sensors of heat and cold are on $\mathrm{t}$ he skin and hy pothalamus. The sensors support the body when skin cools below $34^{\circ} \mathrm{C}$.

The studies of thermal comfort aim to analyze and est ablish condi tions $t \mathrm{o}$ assess whether a thermal environment is o $r$ is $n$ ot su itable fo $r$ human activ ities an $\mathrm{d}$ o ccupations an d also to establish m ethods and pri nciples for a detailed thermal analysis of the environment.

\subsection{Environmental and personal variables}

According to [5] the group of environmental variables $m$ easured in the environm ent is composed of Air Tem perature (airT), $m$ ean radiant temperature (MRT); Relative Air Speed (RAS) an d Relativ e Air Hu midity (RHA). Th is group measures the heat exchange bet ween human body and envi ronment. By the same author, the group of personal variables consists of the $\mathrm{M}$ etabolic $\mathrm{R}$ ate (M), obtained from the table at [12] and the cl othing i nsulation ( $\mathrm{cl} \mathrm{o}$ ), obtained according to [13].

\subsection{Personal variables}

\subsubsection{The metabolic rate $(M)$ :}

Furthermore, [12] clarifies that the metabolic rate $(\mathrm{M}) \mathrm{m}$ easures the energetic value of muscular load and gives a num erical i ndex of activity, being an i mportant fact or in studies of thermal comfort. In warm climates the levels of metabolic heat product ion associ ated wi th muscular work $i$ ncrease body heat and $i$ ts dissipation occurs by evaporating sweat.

The activity resulting metabolism is measured in units "met". One met, which corresponds to 58.2 $\mathrm{W} / \mathrm{m}^{2}$, equals the energy produced per a surface area unit of a body of a person sitting at rest.

The tables in this International Standard regarding $\mathrm{t}$ ot he average individual: - 30 y ears ol d man, wei ghing $70 \mathrm{~kg}$ and bei $\mathrm{ng}$ $1.75 \mathrm{~m}$ tall has body surface area of $1.8 \mathrm{~m}^{2}$.

- 30 years old woman weighing $60 \mathrm{~kg}$ and being $1.70 \mathrm{~m}$ tall has body surface area of $1.6 \mathrm{~m}^{2}$.

Users should make appropriate corrections when they are deal ing wi th special popul ations including children, elderly, people with physical disabilities, etc...

In studies of thermal comfort and stress calculations that require calculation of the skin area that 1 imits the maximum amount of sweat per day for hum ans, the following DuBois equation [2] is used.

$A_{D u}=0.202 . m^{0.425} \cdot l^{0.725}$

where:

$A_{D u}=$ surface area of the nude body, or the

DuBois area $\left(\mathrm{m}^{2}\right)$;

$m=$ body mass $(\mathrm{kg})$;

$l=$ body height $(\mathrm{m})$.

\subsubsection{The thermal insulation of clothing (clo)}

Thermal in sulation is th e resistan ce to sensible heat exchange through a set of clothes. Thermal i nsulation of $\mathrm{cl}$ othing i s m easured by the unit "clo". The "clo" is expressed in $\mathrm{m}^{2} . \mathrm{K} / \mathrm{W}$ or "clo", where $1 \mathrm{cl}$ o equals $0.155 \mathrm{~m}^{2} . \mathrm{K} / \mathrm{W}$. The determination of these val ues was $\mathrm{m}$ ade using heated manikins [5], and $t$ he resul ts of $t$ hese determinations are duly t abulated in ASHR AE standards and $\mathrm{m} \quad$ anuals $[1, \quad 2, \quad 11,13]$.

According to the teachings of the researcher [6], "Neutrality is the thermal condition in which a person does not prefer either more heat or cold over the envi ronment around t hem". For [17] , however: "Thermal neutrality is the condition of 
mind which expresses sat isfaction wi th body temperature as a whole".

\subsection{Determination of indexes $P M V$ and $P P D$}

According to [11], the index PMV (Predicted Mean Vote) Predictive Mean Vote, indicates the thermal sensat ion of peopl e, represent ed by Figure 1 in the scale of [11].

\subsubsection{The PMV index}

\begin{tabular}{|c|c|c|c|c|c|c|}
\hline$-3-2$ & & -1 & 0 & +1 & +2 & +3 \\
\hline $\begin{array}{l}\text { Very } \\
\text { cold }\end{array}$ & Cold & $\begin{array}{c}\text { Slightly } \\
\text { cold }\end{array}$ & Neutral & $\begin{array}{c}\text { Slightly } \\
\text { Warm }\end{array}$ & Warm Hot \\
\hline \multicolumn{6}{|c|}{$\begin{array}{c}\text { Thermal comfort } \\
\text { +0.5 }\end{array}$} \\
\hline
\end{tabular}

Figure 1: Thermal Sensation Scale Source: ISO 7730/2005

The model PM V does not deal di rectly the influence of the climate in the open air. According $t \mathrm{o}[3]$, i n general, persons in the environment of hot climate tend to report that feel more heat in the neutral tem peratures $(-0.5$

$P M V=[0.303 . \exp (-0.036 M)+0.028] L$

where:

$\mathrm{PMV}=$ predicted mean vote PMV, or analytical sense of thermal comfort, dimensionless;

$\mathrm{M}=$ metabolic rate of heat production due to the activity, $\left(\mathrm{W} / \mathrm{m}^{2}\right)$;

$\mathrm{L}=$ heat load acting on the body $\left(\mathrm{W} / \mathrm{m}^{2}\right)$.
$<$ neutral $>+0.5)$.

\subsubsection{PPD index}

Equation [3] is used to calculate the index PMV and the Predictive Mean Vote Estimate.

The PPD index (Predicted Percentage of Dissatisfied), which in dicates the percentage of people dissatisfied with thermal conditions of an environment, is directly related to the PMV and it can be obt ained from $t$ he sam e dat a and software used in the calculation of PM V, or by means of $\mathrm{Fi}$ gure 2 of $\mathrm{t}$ he scheme that is highlighted.
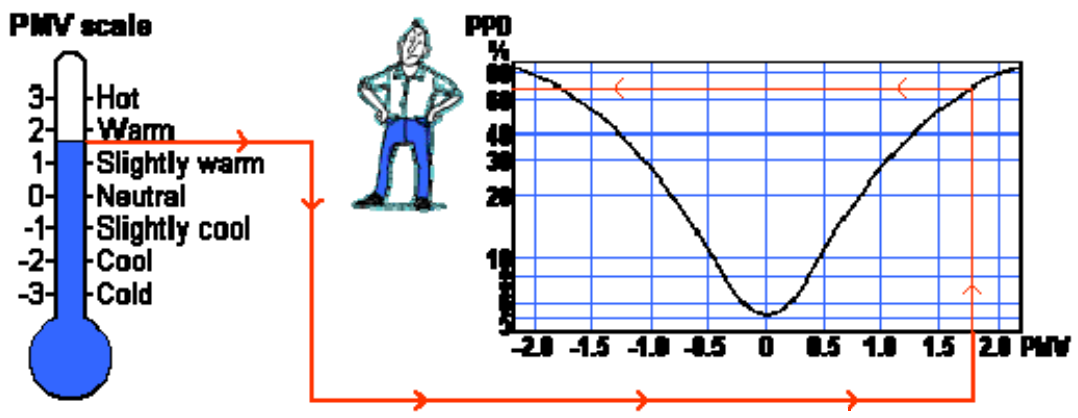

Figure 2: Percentage of People Dissatisfied according to the Predicted Mean Vote (PMV) Source: Innova 
Equation [4] is used to calculate the PPD using the values of PMV.

$$
P P D=100-95 \cdot \exp \left[-\left(0.03353 \cdot P M V^{4}+0.2179 \cdot P M V^{2}\right)\right]
$$

\section{Objective}

The aim of this paper is to identify the correlation $b$ etween th e Pred icted Mean Vote (PMV) called the thermal comfort model studied by [5] and standardized by [11] with the thermal sensation (S).

Report the results declared by 55 employees in $48 \mathrm{~m}$ easurements of si $\mathrm{x}$ envi ronmental variables and two personal variables, called real sensations through a regressi on analysis seeking to est ablish an equat ion between $\mathrm{S}$ and the six variables in the model, identifying the variables that exert the greatest influence on the majority of the employees.

\section{Methodological procedures}

The analyzed variables are composed of two groups: envi ronmental vari ables and personal variables. For $\mathrm{t}$ he col lection of envi ronmental variables the Confortímetro Sensu apparatus was used, in accordance to [10], recording measurements every $30 \mathrm{~m}$ inutes in the workday. Results for the group com posed by the personal characteristics of the clo thing in sulation (clo), were obtained accordi ng to [13] and the Metabolic Rate (M), were obt ained from the table of [12].

Questionnaire with five items was applied in a metal industry located in Ponta Grossa of the State of Parana i n B razil. The fi rst sought information about the wo rkplace, age, weight and height of each re spondent. The second item noted the activity at four di fferent times during the wo rkday. Th e th ird item noted the respondent's $t$ hermal sensat ion across a perception scale of seven poi nts. The fourt $h$ item, on the sam e scale of the previous item , investigated th $\mathrm{e}$ thermal preference of the respondent. Finally, the fifth item identified the clothing used by t he respondent duri ng t he interview. The use of Fanger's $m$ odel and the questionnaire, allowed $\mathrm{t} \mathrm{o}$ creat $\mathrm{e}$ an equat ion whose vari ables i dentified environmental and personal factors of greatest influence in the real sensations reported by employees.

To calculate the indexes PMV and PPD the web tool Human Heat B alance [4] was used. It was fed with th e En vironmental $v$ ariables measured wi th $\mathrm{t}$ he $\mathrm{C}$ onfortímetro Sensu apparatus, according to the standards [10], and with data from the Metabolic Rate (M), obtained from the table of [12] and the clothing insulation (clo), obtained according to [13].

Sensations and preferences were collected through the questionnaire according to the model that will $b$ e p art o $f$ th e An nexes of the dissertation. Measurements followed the precepts of [10].

For data analysis, the software Statistica 6.1 was used with $90 \%$ confidence.

\section{Correlation between the PMV index and true sensations}

The relationship between PMV and sensations showed a determination coefficient of $\mathrm{R}^{2}=0.58$. A set of val ues wi th the regressi on line between the real sensation and the 6 variables of [6] model with a coefficient of determination of $\mathrm{R}^{2}=0.84$ is shown in Figure 1 . The st udy sought $t$ o est ablish $t$ he equat ion between th e th ermal sen sation an $d$ the 6 variables of the model to achieve the equation: $\mathrm{SENS}=0.005 \mathrm{M}+0.05 \mathrm{Tar}+0.17 \mathrm{Trm}-0.01 \mathrm{RH}$ - 2.08 Var - 1.21 clo - 2.18.

Eq. (5) where:

SENS = sensation;

$\mathrm{M}=$ metabolic rate of heat production $\left(\mathrm{W} / \mathrm{m}^{2}\right)$;

Tar $=$ air temperature $\left({ }^{\circ} \mathrm{C}\right)$;

Trm $=$ mean radiant temperature $\left({ }^{\circ} \mathrm{C}\right)$;

$\mathrm{RH}=$ Relative humidity (\%);

Var $=$ relative air velocity $(\mathrm{m} / \mathrm{s})$;

clo $=$ thermal insulation of clothing $\left(\mathrm{m}^{2} . \mathrm{K} / \mathrm{W}\right)$ or

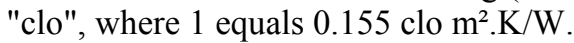




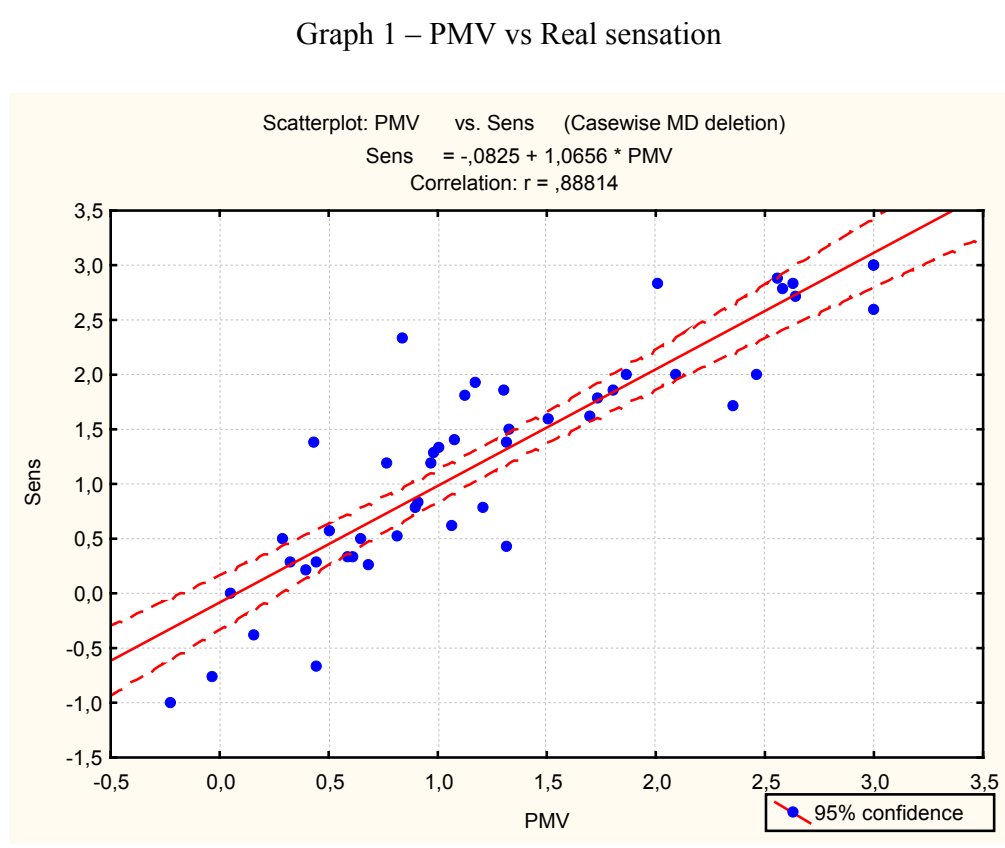

Source: Research data

As a result, it was noted that the mean radiant temperature (ART), air tem perature, and metabolic rate $\mathrm{v}$ ariables co uld im pact thermal sensation of com fort for em ployees i $\mathrm{nt}$ he workplace researched. High tem peratures can cause irritab ility, im paired co ncentration and may be causes of industrial accidents.

The evaporation of sweat can bring the employee present ing i nternal body heat ing in low relativ e h umidity an d high temperature, to feel colder temperature than the one measured in a thermometer. This sensation of coolness on the skin o $\mathrm{f}$ th e em ployee $\mathrm{m}$ ay lead to intensify his/her activities and th is can result in physical harm.

\section{Conclusions}

For better understanding the employees' sensations regardi ng the thermal environment around them, i t was devel oped the equat ion: $\mathrm{SENS}=0.005 \mathrm{M}+0.05 \mathrm{Tar}+0.17 \mathrm{Tm} \mathrm{r}-0.01 \mathrm{RH}$ - 2.08Var - 1.21 clo - 2.18.

The correlation that identified the variable that exerts the greates $t$ in fluence o $n$th ermal sensation was the $\mathrm{m}$ ean radiant tem perature,
MRT group of $t$ he envi ronmental variables was tested.

This $\mathrm{p}$ aper will $\mathrm{b}$ e $\mathrm{p}$ art of the basis of the studies of a master's degree di ssertation and i $\mathrm{n}$ the set of al $1 \mathrm{~m}$ easurements; discussions and suggestions will be made.

\section{Acknowledgements}

The authors thank Fundação Araucaria Agency to prom ote the re search of the State of Parana, B razil, for fi nancial support to present this paper at the IEA $2012-18^{\text {th }}$ World Congress on Ergonom ics i n R ecife - February 2012.

\section{References}

[1] AMERICAN SOCIETY OF HEATING, REFRIGERATING A ND A IR CONDITIONING ENGINEERS, INC. Thermal Environmental Conditions for Human Occupancy, ASHRAE Standard 55-1992. Atlanta, 2005.

[2] ASHRAE Fundamentals. Atlanta, 2005 Cap.8: Thermal Comfort.

[3] de Dear, R. J. \& Brager, G. S. (1998). Developing an adaptive model of thermal co mfort and preference. ASHRAE Transactions, 104(1), 1-18. 
[4] de Dear, R. Hum an Heat Balance. University of Australia, Sydney. Access in 10/02/2011<

http://web.arch.usyd.edu.au/ rdedear>

[5] Fanger, P.O., 1970, "Thermal Comfort - Analysis and Applications in Environmental Engineering", United States, McGraw-Hill Book Company.

[6] Fanger, P. O . Thermal Confort, Analysis and Applications in Environmental Engineering. New York, McGraw-Hill Book Company, 1972.

[7] Fontanella M.S; Souza H.A . Avaliação de índices de conforto térmico entre os univer sitários na cidade de Ouro Preto.In:X ENCAC, Natal,outubro,2009.

[8] Givoni, B. Com fort Clim ate Analysis and Building Design Guidelines. Rev. Energy and Buildings. Lausanne: v. 18, n. 1, p. 11-23, 1992.

[9] Innova, Air Tech I nstruments. T hermal $\mathrm{C}$ omfort. Access in $17 / 10 / 2010$ $<$ file://K:Marketing $\backslash$ HomepagelGammel\%20Homepa gelWebsitelbooks $\backslash$ thermal $\backslash$ therm...>

[10] INTERNATIONAL ORGANIZATION FOR STANDARDIZATION. Ergonomics of the thermal environment - Instruments for measuring physical quantities, ISO 7726. Genebra, 1996, 39p.

[11] . Ergonomics of the thermal environment Analytical determination and interpretation of thermal comfort using calculation of the PMV and PPD indices and local thermal comfort, I SO 7730, Genebra, 2005.
[12] Determination of metabolic rate, ISO 8996, Genebr a, 2004.

[13] . Ergonomics of the thermal environment Estimation of thermal insulation and water vapou resistance of a clothing ensemble, ISO 9920, Genebr a 2007. Second edition 2007/06/01.

[14] Oliveira,S.J.F. Conforto tér mico no am biente de trabalho: avaliação das variáveis subjetivas da percepção do calor. Available in: http://www.aedb.br/seget/artigos10/201_ARTIGO $\% 2$ 0-\%20SEGET.pdf.: 24/11/2010.

[15] Olgyay, V. Design with climate. New Jersey: Princeton University, 1963.

[16] Szokolay, S. V. Thermal Design of Buildings. Australia: Raia Education Division, 1987.

[17] T anabe, S. Thermal Comfort Requirements in Japan. Waseda, 1984. T ese de Doutorado - Waseda University.

[18] Xavier, A.A P. Condições de Confor to Térmico para Estudantes de $2^{\circ}$. Gr au na Região de Florianópolis. 198f. Dissertação (Mestrado em Engenharia Civil) Departamento de Construção Civil da Univer sidade Federal de Santa Catarina, Florianópolis, 1999. 